\title{
Corporate Governance and Bank Competition Empirical Study on the Jordanian Commercial Banks Listed in Amman Stock Exchange over the Period (2001-2014)
}

\author{
Dr Abdulrahman Hashem \\ Assistant Professor, Department of Banking and Finance \\ Al Isra Private University \\ Mr. Fadi Ayoub \\ Lecturer, Department of Banking and Finance \\ Al Isra Private University \\ Dr. Haitham Bani Ata \\ Assistant Professor, Department of Administration and Finance \\ University College of Ajloun - Balqa' Applied University
}

Received: Nov. 5, 2015 Accepted: Dec. 9, 2015 Published: December 9, 2015

doi:10.5296/ajfa.v7i2.8606 URL: http://dx.doi.org/10.5296/ajfa.v7i2.8606

\begin{abstract}
The purpose of this paper is to identify the effect of corporate governance implementation on the commercial banks' competition in Jordan. Bank competition is tested by using Panzar and Rosse H statistics model and the researchers applied it on the collected data into two periods of time (2001-2007 and 2008-2014), taking into consideration that corporate governance was first implemented in the Jordanian banking sector on 31/12/2007. The researchers used Mann-Whitney Test to compare the results of both time phases. The results showed insignificant effect of corporate governance on bank competition that can be linked to certain reasons including the immaturity of corporate governance's implementation in the Jordanian banking sector, the socio political upheavals that affected Jordan, and the differentiation of bank services between banks led to a more monopolistic behavior. This paper urges other researchers and practitioners to take their role into updating and modifying corporate
\end{abstract}




\section{Macrothink}

Asian Journal of Finance \& Accounting ISSN 1946-052X 2015, Vol. 7, No. 2

governance to positively enhance bank competition taking into account the political turbulences in the neighboring countries and the movement of cash across the region and passing the country.

Keywords: Bank Competition, Panzar and Rosse H Statistics, Monopoly, Monopolistic Competition, Corporate Governance 


\section{Introduction}

The major collapses of high profile companies in leading countries, have produced a need to create general systems, processes and practices to control and direct any firm or institution. Consequently, corporate governance was launched in early 2002 to retrieve the shareholders' trust against self-interest directors and managers.

Many scholars tried to limit the reasons despite the fact of its well-known reasons. According to Becht and others: "Why has corporate governance become such a prominent topic in the past two decades or so and not before? We have identified, in no particular order, the following reasons: i) the worldwide wave of privatization of the past two decades; ii) pension fund reform and the growth of private savings; iii) the takeover wave of the 1980s; iv) deregulation and the integration of capital markets; v) the 1998 East Asia crisis, which has put the spotlight on corporate governance in emerging markets; vi) a series of recent USA scandals and corporate failures that built up but did not surface during the bull market of the late 1990s" (Becht et al, 2002)

In the beginning of the $21^{\text {st }}$ century, the financial crises had put the developed countries in a time race to apply corporate governance on the banking industry to maintain its financial and managerial stability. This is when Basel Committee had launched principles to help protect banking discipline. It is well known that the role of the banking sector is essential in well working economies, where financial systems have a tendency to advance around it, trying to achieve economies of scale to balance the expenses of gathering and preparing data outlined to lessen uncertainty and encouraging a productive distribution of financial resources. Banks tend to work as quality controllers of capital looking for fruitful ventures, guaranteeing higher returns and speeding up yield growth. However, a competitive banking system must be maintained to ensure the integrity of banks' role in monetary intermediation to channel funds into investments that will result in higher economic growth rates and increase of shareholders' wealth.

Since the beginning, the Jordanian economy is still facing different challenges and difficulties due to numerous socio-political-economic factors including the political upheavals in the region, rising unemployment rates and major dependency on the remittances from the Gulf countries. The growth of banks and its important role in stabilizing the national economy is not only due to their financial performance, but also to the willingness amongst the industry leaders to focus on continuous alterations in the stakeholder concerns.

The Central Bank of Jordan (CBJ) is the key player in enhancing corporate governance. In 2004, the CBJ issued the bank Director's Handbook of Corporate Governance, and continued its efforts to enhance corporate governance in the Jordanian banking system by issuing new instructions that are in line with the principles of the Basel Committee on Banking Supervision, the Organization for Economic Cooperation and Development (OECD), and the Financial Stability Board to address loopholes exposed by the global financial crisis in financial institutions' governance.

On the other hand, bank competition was and still one of the hot topics to be discussed and 
tested. One of the most important models, that were basically developed to quantitatively assess the competitive conditions in the banking sector, is the Panzar - Rosse approach. Panzar - Rosse H Statistics model gauges the degree of banking contestability in terms of the variations between banks' pricing strategies in response to changes in their input costs. In this study, the researchers intend to study the degree of competition before and after implementing corporate governance in the Jordanian commercial banks between 2001-2014, by using Panzar - Rosse $H$ Statistics model in order to answer the main question whether corporate governance affect the degree of bank competition in the Jordanian commercial banking sector or not?

\subsection{Corporate Governance Definition:}

There are several definitions of corporate governance but one of the most comprehensive definitions that the researchers find adequate is the following statement "corporate governance refers to a set of rules and incentives by which the management of a company is directed and controlled. Good corporate governance maximizes the profitability and long-term value of the firm for shareholders", (Khumani et al., 1998).

\subsection{Research Objective:}

The objective of this experimental research is centered on determining the effect of corporate governance on the degree of competition of the Jordanian commercial banks. The result will be highly important in recognizing the effect of corporate governance on bank competition and its role in reducing the gap between banks and unifying the base of processes and standards. What distinguishes this study from others is the use of Panzar and Rosse $\mathrm{H}$ statistics in determining the degree of competition in the absence and presence of corporate governance.

\section{Literature Review:}

The researchers aim to identify two groups of previous literatures. The first group is focused on bank competition review (Panzar and Rosse Approach):

Panzar and Rosse (1977) Panzar and Rosse (1987) had issued certain models to measure the degree of competition. $H$ statistics computes the percentage change in a bank's equilibrium revenues caused by one percent change in the entire bank's input prices.

One of the first uses of the Rosse-Panzar system to banking sector was a multiple cross sectional studies by Shaffer (1982), which inspected the competitive situation for a sample of unit banks in New York by evaluating a bank revenue equation in which total revenue is tested by variables like interest revenue, the unit prices of labor, capital, bank funds, and other variables affecting the long-run equilibrium bank revenues. Shaffer used a regression relating the return on bank assets to bank input prices. His results found $\mathrm{H}$ ranging from .32 to .36 for the competitiveness test.

Nathan and Neave (1989) used the same equation to test competition in Canadian banks, trust companies, and mortgage companies between 1982-1984. The results showed perfect competition in the year 1982 as the value of $H=1.058$, however in 1983 and 1984 they found 
$H=0.680$ and 0.729 , respectively which indicates monopolistic competition.

Lloyd-Williams et al, (1991), tested Panzar and Rosse formula on a sample of 72 Japanese commercial banks from 1982 to 1988 . They found that the 1986 values of $H$ range between -0.004 and -0.006 , which are both significantly different from zero and unity. They are, therefore, unable to reject the monopoly or hypothetical variations short-run oligopoly hypotheses for Japanese commercial banks. However, for 1988 the values of $H$ range between 0.245 and 0.423 , suggesting monopolistic competition.

Bikker and Haff (2002) examined Panzar and Rosse approach on banking industry in 23 countries. In order to distinguish competitive behavior on local, national and international markets, for each country, three sub-samples were taken: small or local banks, medium-sized banks and large or international banks. For all 23 countries showed monopolistic competition

Mamatzakis et al (2005) measured the degree of concentration and competition in banking sector in the south eastern European region over the period 1998-2002. They separately applied PR on two dependent variables which are interest revenue and total operating revenue. The results showed monopolistic competition with a significant regular improvement in terms of competition.

Hashem (2006) studied the commercial banks in Jordan in the period of 1997-2004. PR approach was applied and showed monopolistic competition where $H$ statistics $=.654$. This study recommended large banks to split into smaller ones in order to enhance the competitiveness.

Fayoumi et al (2012) studied bank competition in mainly six Middle Eastern and North African (MENA) countries for the period from 1998 to 2007. The results reveal that the banking market structure can be characterized as monopolistic competition. One of the recommendations of this study was to enforce and enhance the role of corporate governance in the banking sector.

Since Berle and Means (1932) indicated on the importance of separating ownership and control in modern corporate structure, most literature concentrated on the well known agency problem between shareholders and managers without much of focus on common corporate governance codes to be applied inside corporations and banks.

The second group is this study's literature is focused on linking competition to corporate governance. One of the first studies that linked competition and corporate governance is the study of Allen, Gale (1999). They examined the US, UK, France, Germany and Japan markets and their results showed that in US and UK markets, the threat of take-over ensures that managers act in the shareholders' interest. While in France, Germany and Japan markets, it's suggested that the banks and other institutions should act as monitors. However they argued that neither system is effective as competition between firms may be more effective in ensuring that the resources are used efficiently.

Ciancanelli, Gonzalez (2000) aimed to demonstrate the limitations of the assumption saying that banks conform to the concept of the firm used in Agency Theory. They aimed also to 
propose an alternative conceptual framework more suitable to its analysis. They argued that commercial banks are distinguished by a more complex structure of information asymmetry arising from the presence of regulation. Their study showed that regulation limits the power of markets to discipline the bank, its owners and its managers and they argued that regulation must be seen as an external force, which alters the parameters of governance in banks.

Crespi et.al (2004) examined two issues in the corporate governance applied in Spanish banks. The two main questions are: does poor economic performance activate governance interventions that favor the removal of executive directors and the merger of non-performing banks? and does the relationship between governance intervention and economic performance vary with the ownership form of the bank?

The results of this study found a negative relationship between performance and governance intervention for banks, however the results changed for each form of ownership and each type of intervention. Product-market competition compensates for those weaker internal governance mechanisms and non-performing banks are not totally protected from disappearing.

Levin (2004) discussed two special characteristics of banks that make them special in practice: low transparency than other industries and greater government regulation. The results showed that it is important to strengthen the ability and incentives of private investors to exert governance over banks rather than relying excessively on government regulators.

Price et al (2011) studied the relation between compliance with the code of 'Best' Corporate Practice and performance. The Code was developed to offer information to market participants regarding the governance strength of firms trading on the Mexican stock exchange. There results indicated that compliance generally not linked with improved performance, suggesting that monitoring alone is not enough to bring about fundamental changes.

Chaudhry (2012) examined the interaction of product market competition with corporate governance variables affects the performance of a corporation in the Indian market. This study importantly concluded that: greater competition tends to show up in greater variations in standards of firms-level governance both within countries and among countries. Firms operating in a competitive environment need to display superior corporate governance quality in comparison to their peers in order to gain access to resources and to enhance their credibility. Also, it is the tendency to increase relative corporate governance scores that drives the observed divergence.

\section{Hypothesis of the study:}

This study shall test the following main null hypothesis:

H01: There is no effect of corporate governance on the degree of competition in the Jordanian commercial banking sector in the period 2001-2014 


\section{Research Methodology:}

This research studies the effect of corporate governance application and the degree of bank competition. Panzar and Rosse $H$ statistics model was applied on the sample comprised of 13 commercial banks operated in the period between 2001 and 2014, and linked it to corporate governance application which effectively took place on 31/12/2007 according to the Central Bank of Jordan. (Code of Corporate Governance)

The followed methodology applied Panzar and Rosse $H$ statistics model on the sample by calculating the $H$ statistics (i.e., the level of competition) every year from the year 2001 until 2014. The researchers divided the study into two phases: the first one is from $2001-2007$ to show the degree of competition before implementing corporate governance, while the second phase took the period from 2008 - 2014 and tested the degree of competition after implementing corporate governance.

The Panzar and Rosse (PR) model is as follows:

$\ln$ TRASS $_{\text {it }}=a+H 1 \ln \mathrm{PL}_{\text {it }}+H 2 \ln \mathrm{PK}_{\text {it }}+H 3 \ln \mathrm{PF}_{\text {it }}+e \ln \mathrm{ASS}_{\mathrm{it}}+f \ln \mathrm{LN} \mathrm{ASS}_{\text {it }}+g \ln$ CAP ASS ${ }_{\text {it }}+k \ln$ IBTDEP $_{\mathrm{i}}$

for $\mathrm{t}=1, \ldots ., \mathrm{T}$ where $\mathrm{T}$ is the number of periods observed ( 6 years), and $\mathrm{i}=1, \ldots \ldots, \mathrm{I}$, where $\mathrm{I}$ is the total number of banks (13 banks).

Where:

The dependent variable:

TRASS: Total interest revenue per Jordanian dinar (JD) of assets.

The independent variables:

PL: is the personnel expenses per Jordanian dinar of assets (proxy for unit price of labor),

PK: is the Operating expenses per Jordanian dinar of fixed assets (proxy for unit price of capital),

PF: is the ratio of annual interest expenses to total funds (unit price of funds).

The control variables:

ASS: is the bank assets, (bank's size)

LN ASS: is the loans to assets ratio,

CAP ASS: is the total capital (Equity) to assets ratio, and

IBTDEP: is the interbank deposits to total deposits. That is, the ratio of the bank's deposits in other banks to the total deposits in the bank.

ln: is the Natural Logarithm, was applied

After applying the PR model onto both phases, the researchers shall compare the $H$ statistics results for each year to determine whether corporate governance affected the degree of 
competition or not by using Mann Whitney Test

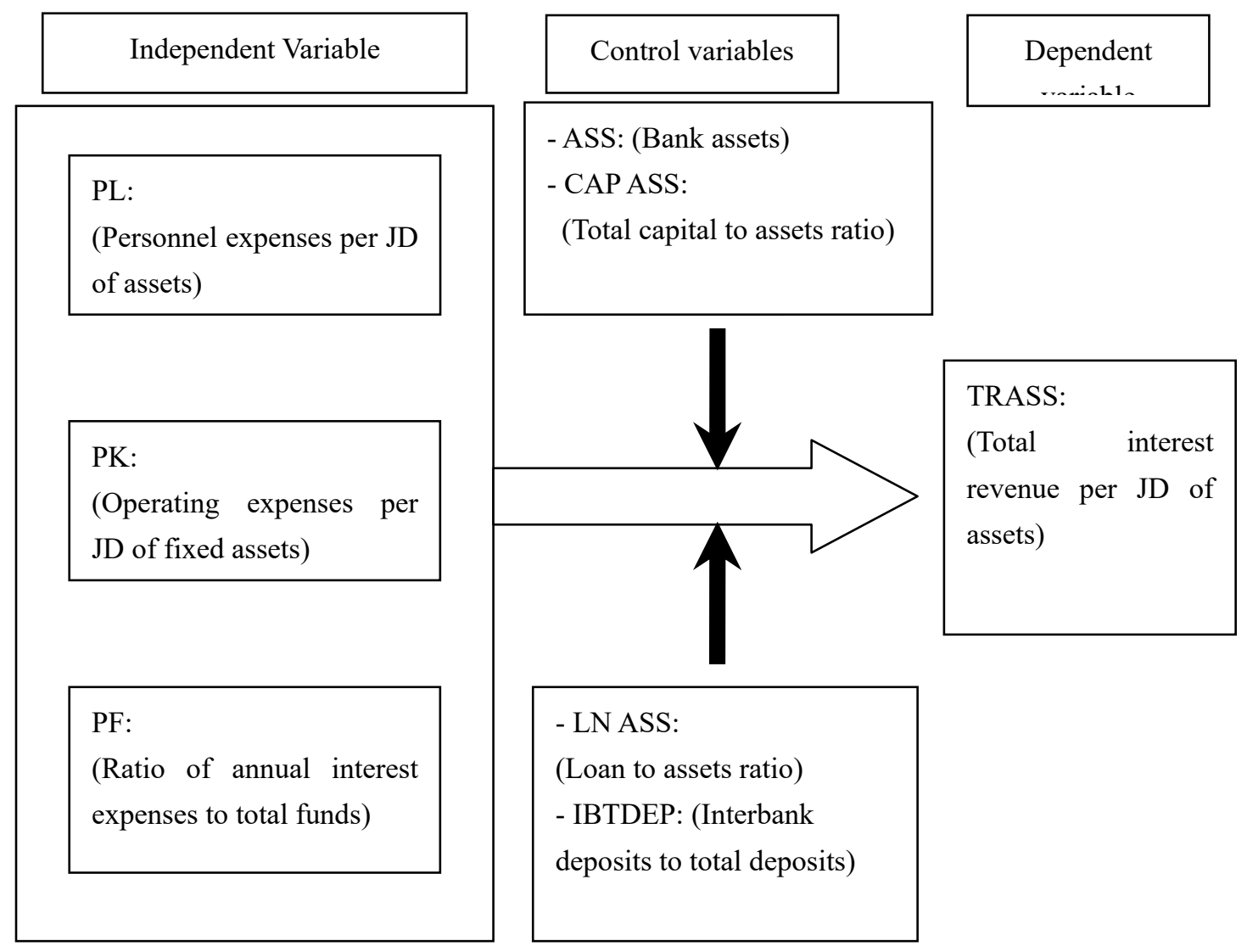

Figure 1. Variables Relationship Diagram

Source: by the researchers

Under the PR framework, the $\mathrm{H}$ statistic is equal the sum of the elasticities of the revenue with respect to the three input prices: $\mathbf{H}=\mathbf{H} \mathbf{1}+\mathbf{H} \mathbf{2}+\mathbf{H} \mathbf{3}$

Results are interpreted as follows:

$\mathrm{H}=1$ Perfect competition
$0<\mathrm{H}<1$ Monopolistic competition
$\mathrm{H} \leq 0$ Monopoly (or perfectly collusive behavior).

\section{Results:}

H01: There is no effect of corporate governance on the degree of competition in the Jordanian commercial banking sector in the period 2001-2014 


\section{Macrothink}

Asian Journal of Finance \& Accounting ISSN 1946-052X 2015, Vol. 7, No. 2

This study used the Mann-Whitney test using SPSS package, to analyze the data collected from the bank annual reports from 2001-2014 provided by Jordan Securities Commission (JSC).

Table 1. Degrees of competition according to PR $H$ statistics

\begin{tabular}{|l|l|l|l|l|l|l|l|l|l|l|l|l|l|l|}
\hline Year & 2001 & 2002 & 2003 & 2004 & 2005 & 2006 & 2007 & 2008 & 2009 & 2010 & 2011 & 2012 & 2013 & 2014 \\
\hline H Stat. & 0.344 & 0.532 & 1.083 & 0.345 & 0.45 & 1.391 & 0.113 & 4.668 & -0.159 & -5.241 & -1.816 & 0.352 & 0.616 & 0.477 \\
\hline
\end{tabular}

After applying the regression model of PR $H$ statistics on each year in the sample, the researchers reached to the above degrees of competition (the sum of $H 1, H 2$ and $H 3$ ).

Mann-Whitney Test is used to test above hypothesis and it is found that Wilcoxon $\mathrm{W}=$ 47.000 is not significant at 0.05 level so that there is no effect of corporate governance on the degree of competition in the Jordanian commercial banking sector over the period 2001-2014.

Table 2. Variables Descriptive Analysis

\begin{tabular}{|ll|l|l|l|}
\hline & & $\mathrm{N}$ & Mean Rank & Sum of Ranks \\
\hline $\mathrm{H}$ & .00 & 7 & 8.29 & 58.00 \\
& $\begin{array}{l}1.00 \\
\text { Total }\end{array}$ & 7 & 6.71 & 47.00 \\
\hline
\end{tabular}

Table 3. Hypothesis Test

\begin{tabular}{|l|l|}
\hline & H \\
\hline Mann-Whitney U & 19.000 \\
Wilcoxon W & 47.000 \\
Z & $-.703-$ \\
Asymp. Sig. (2-tailed) & .482 \\
Exact Sig. [2*(1-tailed Sig.)] & $.535^{\text {a }}$ \\
\hline
\end{tabular}




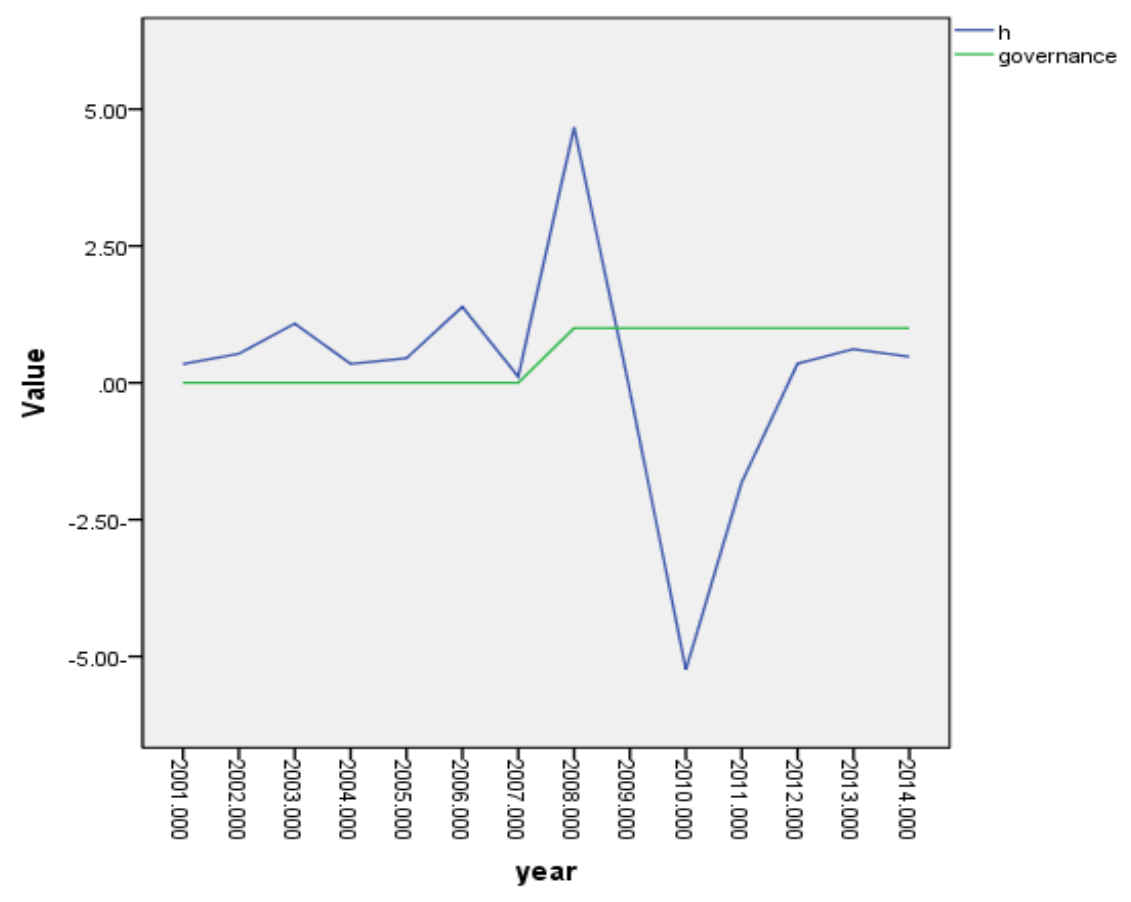

Figure 2. Variables Relationship Chart.

Above chart reflects the differences in PR $H$ statistics and are not related to applying corporate governance

\section{Conclusions:}

This paper examines the effect of corporate governance on the degree of competition in the commercial banking sector in Jordan. This paper used Panzar and Rosse model to test $H$ statistics that indicates the degree of competition in each year in this study. The degree of competition was compared between two phases: the first one is before implementing corporate governance (between 2001-2007) and the second one is after implementing corporate governance (2008-2014). The results showed some more consistency in the first phase as the maximum level of competition that exceeded 1 to achieve perfect competition, but also declined to as low as 0.113 (monopolistic competition). On the other hand, the second phase witnessed great variations in the results as the minimum level of competition was -5.241 , which indicates perfect monopoly and the maximum was 4.668 . The aim of this result is to show if there is an effect of corporate governance on the degree of competition.

This should lead us to a question, whether corporate governance is doing its job in enhancing the competition between commercial banks? Apparently, the current version of corporate governance is not playing the expected role that is expected from it. This may be linked to certain reasons:

- Corporate governance application is still considered immature. Although the Central Bank of Jordan claims that the starting date of corporate governance was in early 2008, the real implementation in practice would have taken few years after 2008.

- The financial services provided by banks are sometimes monopolized. 
- Reference to Hashem (2006) study, one of his recommendations was about splitting banks to reduce assets' sizes because of the negative relationship between total bank assets and total interest revenue. Since corporate governance codes add more discipline on market entrance, which may negatively affect the competition and drive it toward monopoly such as in our case here.

- Corporate Governance regulated the market and added more discipline to banks internal procedures. This added more pressure on banks to rearrange its procedures to operate in a safer environment. This resulted by gaining the trust of investors, shareholders, and depositors. This gave advantage to certain banks to enhance their position in the market and increase their share in the market.

- The socio-political upheavals including the Syrian war (refugees problem), had led to increase the challenge between banks in terms of deposits and loaning benefits

- The differentiation of bank services and products between banks, added a possible significant affect on attracting deposits and loan applications, therefore more monopolistic behavior..

\section{Recommendations}

The researchers recommend the following:

- Enhance corporate governance awareness in the banking industry.

- Future research can compute the competition level in presence of foreign banks as well as the Islamic banks.

- Exploring the corporate governance layers that affect the bank competition and modify according to the actual need of the banking sector.

\section{References}

Al-Fayoumi, N., \& Abuzayed, B. (2010). Competitive Conditions in MENA Banking Markets. Allen, F., \& Gale, D. (1999). Corporate governance and competition. University of Pennsylvania.

Becht, M., Bolton, P., Roell, A., 2002. Corporate Governance and Control. ECGI-Finance Working Paper, 2.

Bikker, J.A., Haaf, K. (2002) Measures of competition and concentration in the banking industry: a review of the literature (Electronic Version). Economic \& Financial Modeling, 9, 53-98.

Central bank of Jordan. (2007). Corporate governance code for banks in Jordan.

Chaudhry, Y. (2012). Corporate governance in India. Journal of Resources, Energy and Development, 9(1), 52-53.

Ciancanelli, P., \& Reyes-Gonzalez, J. A. (2000). Corporate governance in banking: a 
conceptual framework. Available at SSRN 253714. http://dx.doi.org/10.2139/ssrn.253714

Crespí, R., García-Cestona, M. A., \& Salas, V. (2004). Governance mechanisms in Spanish banks. Does ownership matter?. Journal of Banking \& Finance, 28(10), 2311-2330. http://dx.doi.org/10.1016/j.jbankfin.2003.09.005

Hashem, A. (2006). Competitive Conditions in the Jordanian Banking sector: Empirical Study. (Unpublished master's thesis). University of Jordan, Jordan.

Levine, R. (2004). The corporate governance of banks: A concise discussion of concepts and evidence (Vol. 3404). World Bank Publications. http://dx.doi.org/10.1596/1813-9450-3404

Lloyd-Williams, D.M., Molyneux, P., \& Thornton, J. (1991). Competition and contestability in the Japanese commercial banking market. (Electronic Version). Institute of European Finance Research Papers in Banking and Finance, 16.

Mamatzakis, E., Staikouras, C., \& Koutsomanoli-Fillipaki, N. (2005). Competition and concentration in the banking sector of the south eastern European region (Electronic Version). Emerging Markets Review, 6, 192-209. http://dx.doi.org/10.1016/j.ememar.2005.03.003

McCraw, T. K. (1990). Berle and Means.

Price, R., Román, F. J., \& Rountree, B. (2011). The impact of governance reform on performance and transparency. Journal of Financial Economics, 99(1), 76-96. http://dx.doi.org/10.1016/j.jfineco.2010.08.005

Panzar, J.C., \& Rosse, J.N. (1987). Testing for monopoly equilibrium (Electronic Version). Journal of Industrial Economics, 35, 443-456. http://dx.doi.org/10.2307/2098582

Rosse, J.N., \& Panzar, J.C. (1977). Chamberlin vs Robinson: An empirical study for monopoly rents. (Electronic Version). Bell Laboratories Economic Discussion Paper

Shaffer, S. (1982). A non-structural test for competition in financial markets, Proceedings of a Conference on Bank Structure and Competition. Federal Reserve Bank of Chicago, USA, pp. $225-243$.

Stone, A., K. Hurly, and R. Khumani. (1998). Business Environment and Corporate Governance: Strengthening Incentives for Private Sector Performance, the World Bank/IMF Annual Meetings.

\section{Copyright Disclaimer}

Copyright for this article is retained by the authors, with first publication rights granted to the journal.

This is an open-access article distributed under the terms and conditions of the Creative Commons Attribution license (http://creativecommons.org/licenses/by/3.0/). 